\title{
استفتاء في قضية تختص بتجديد فهم الدين: \\ ما هي أيام الحج في العالم المعاصر؟
}

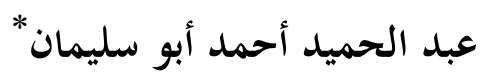

مقدمة: - مقا

انطلقت في الذهن في ظل الظروف المعاصرة، تساؤلاتُ أظن أفها توجب التجديد في

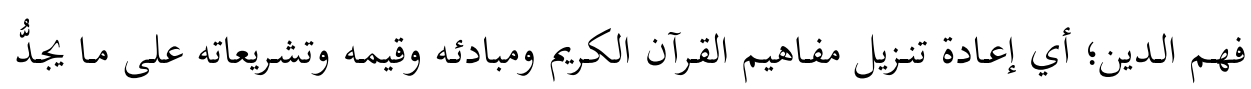

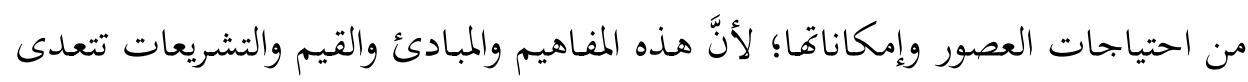

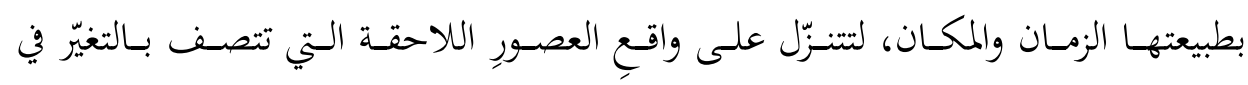
الإمكانات والاحتياجات.

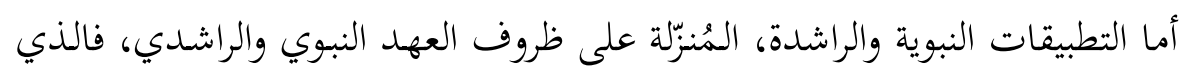

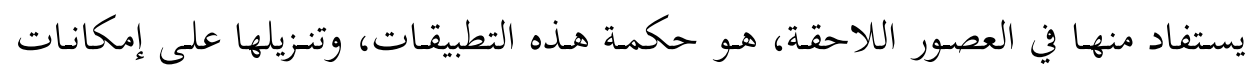

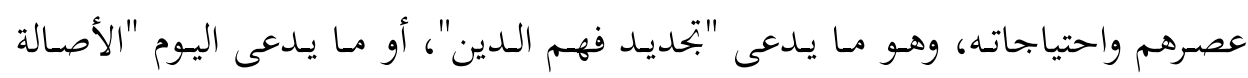
المعاصِة"، أو "الأصالة والمعاصَرة"، أو "إسلامية المعرفة".

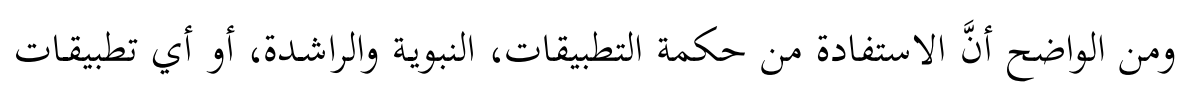

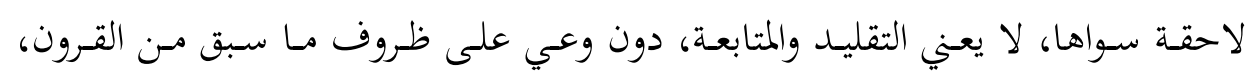

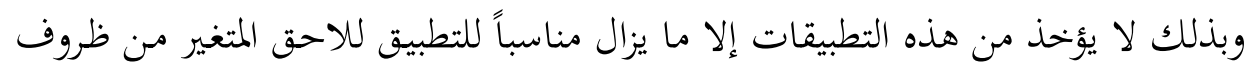

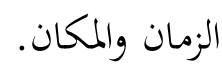

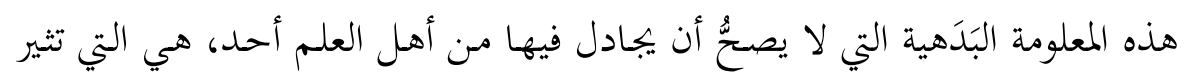

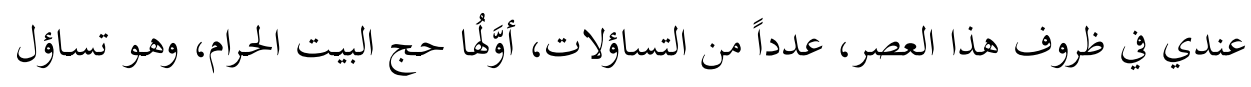

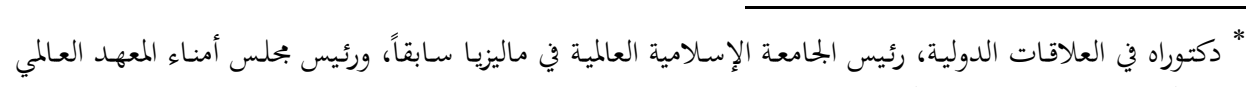

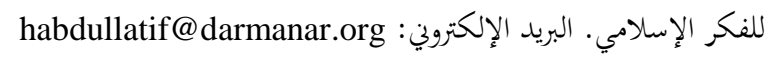




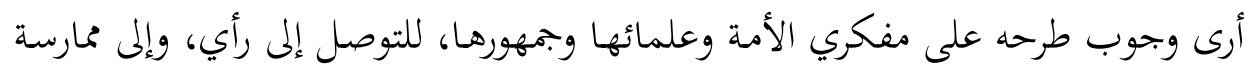

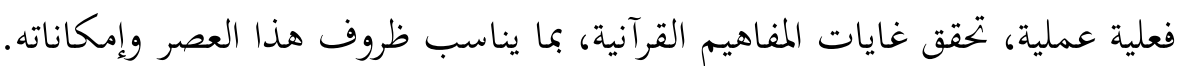

\section{أوّلاً: حج البيت ومستجدات العصر}

ومما أسهم في إثارة هذا التساؤل عندي، هو أنني واحد من أبناء مكة المكرمة، حسَّ

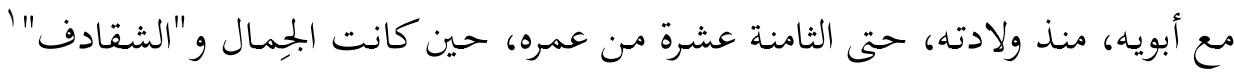

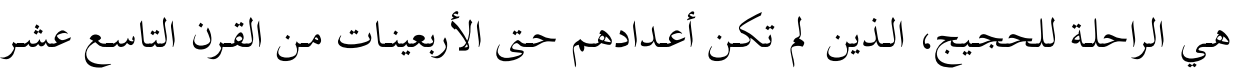

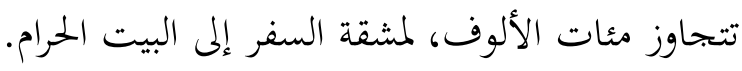

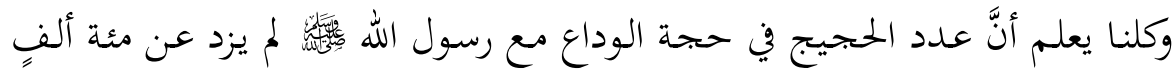

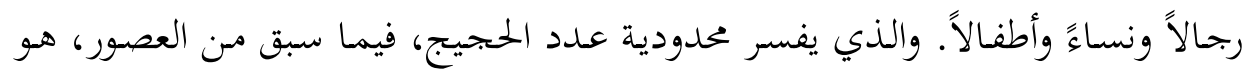

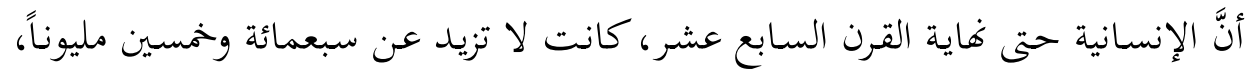

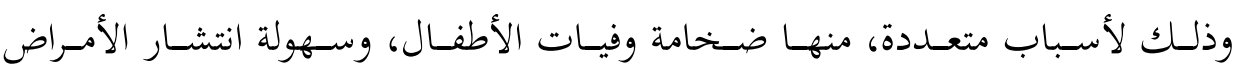

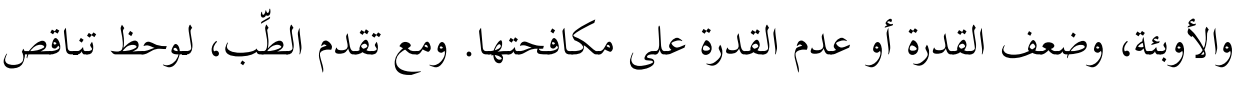
وفيات الأطفال، وتزايد القدرة على مكافحة الأمراض، وارتفاع متوسط أعمان العار العار البالغين.

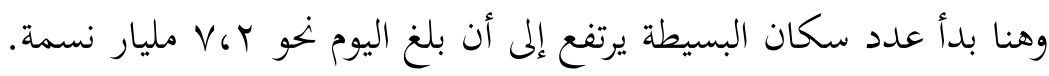

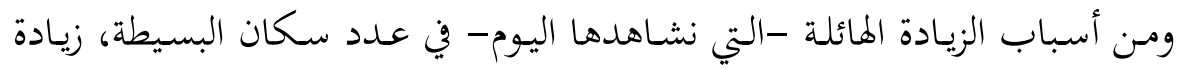

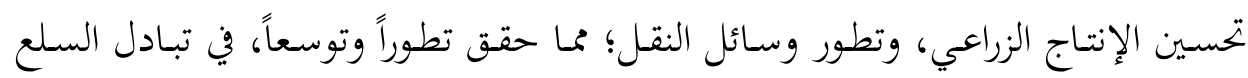

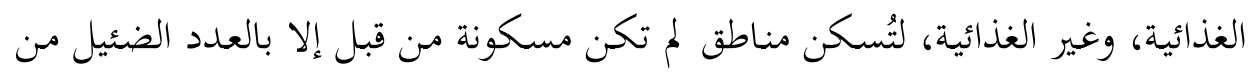

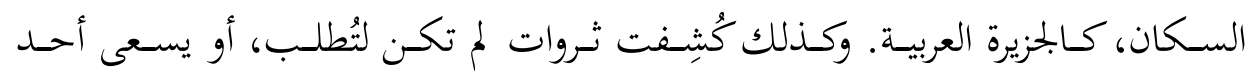

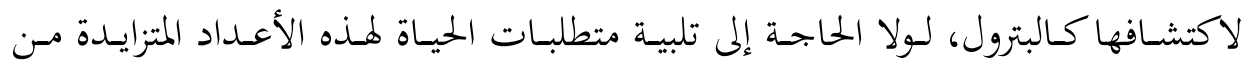

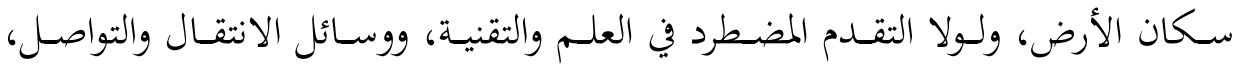
وسهولة تبادل السلع والمنتجات. ولما كان الحهج فريضة على كل مسلم، مرةً واحدة في العمر، ما بـات بين سن الخامسة

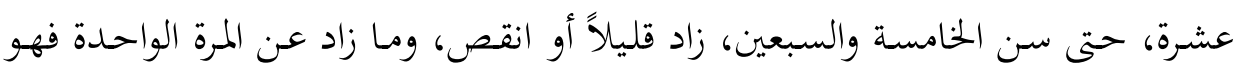

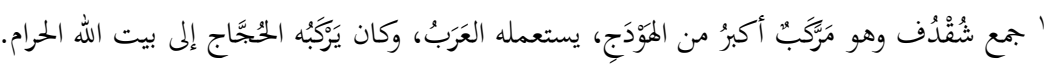




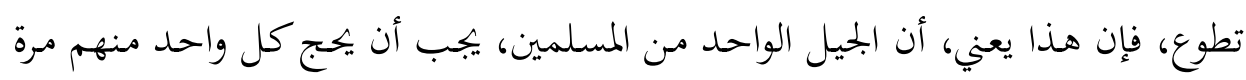

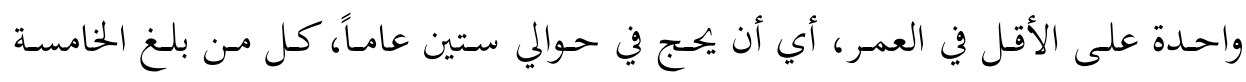

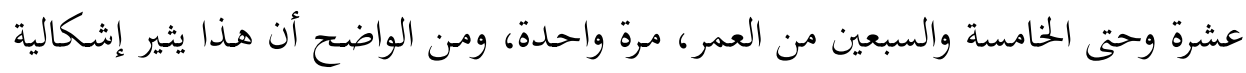

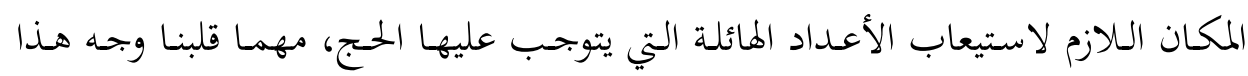

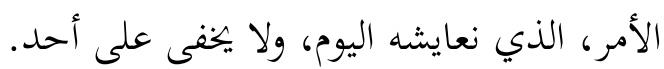

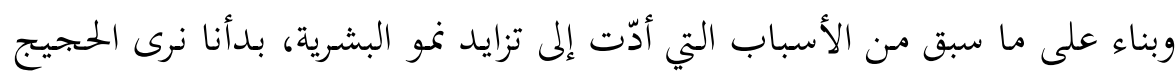

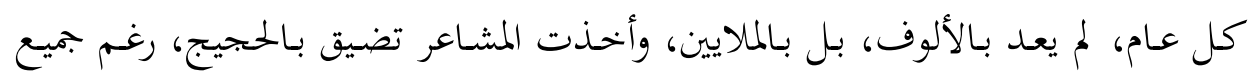

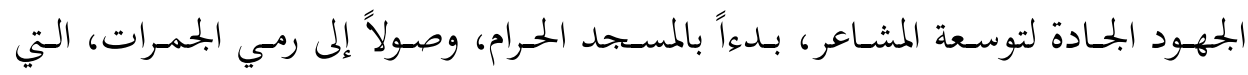

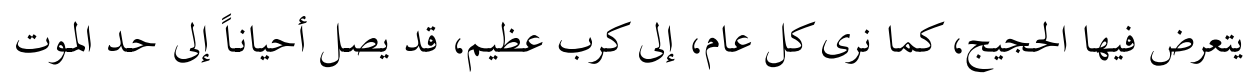

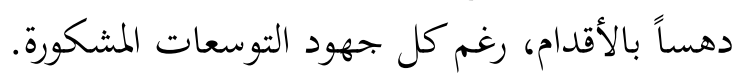

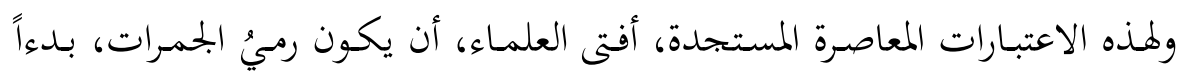

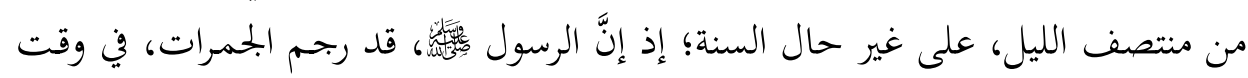

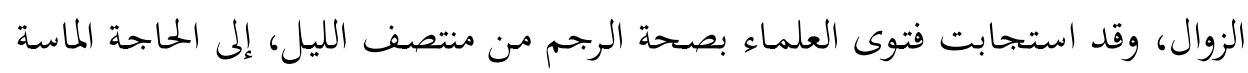

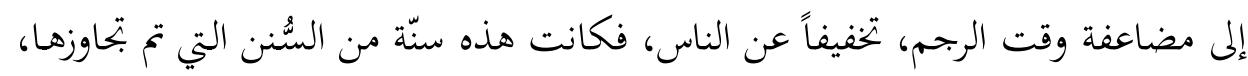

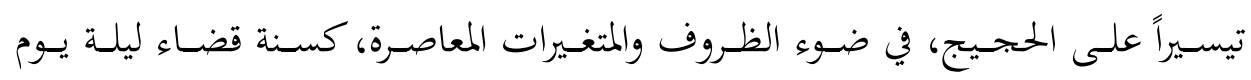

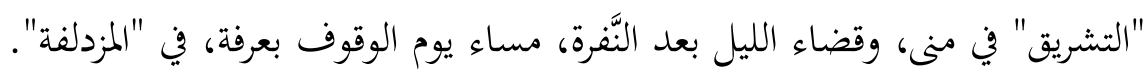

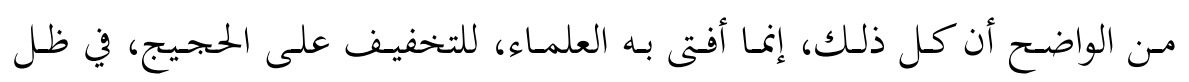

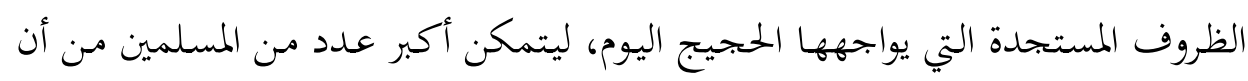
يؤدي فريضة الحج، بأقل قدر ممكن من العناء.

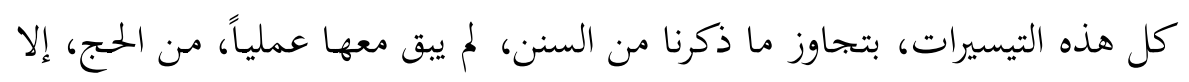

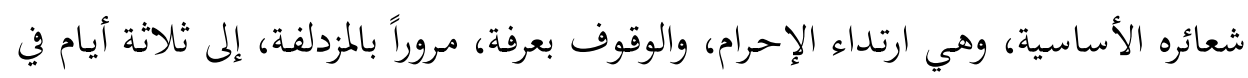

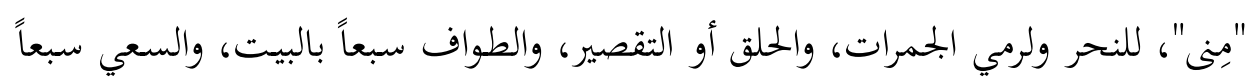

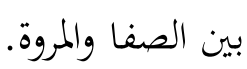

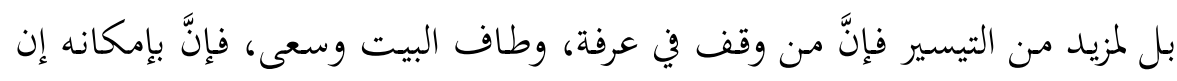

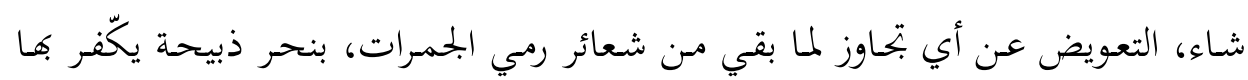
عن التقصير، وتكون طعاماً للفقراء، وذوي الحاجة. 
ثانياً: ضيق المكان يتحكم في عدد من يؤدي الفريضة

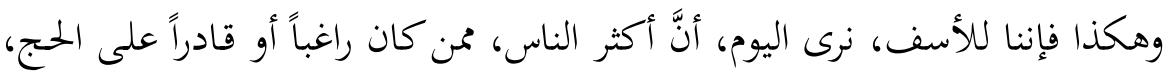

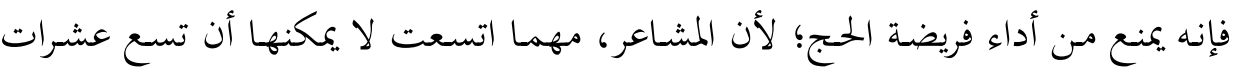

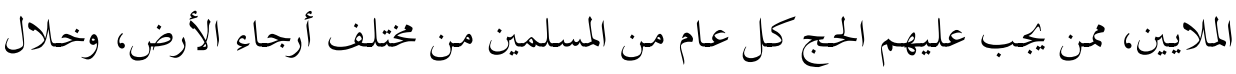

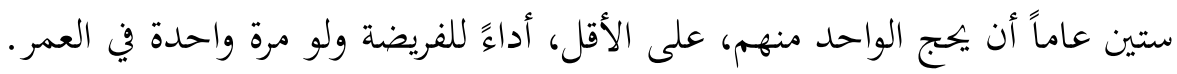

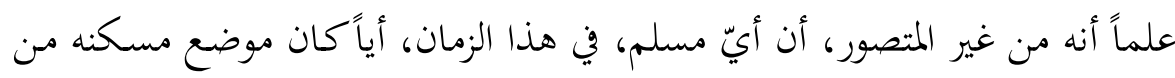

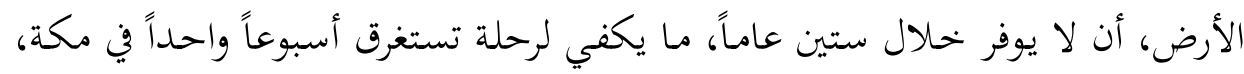

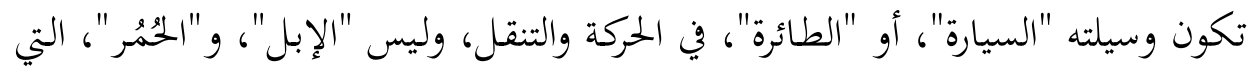

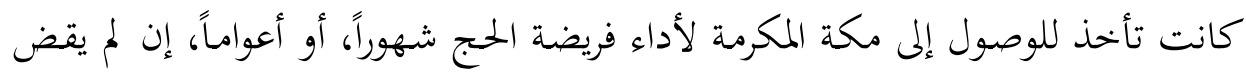

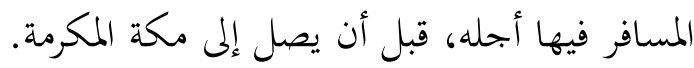

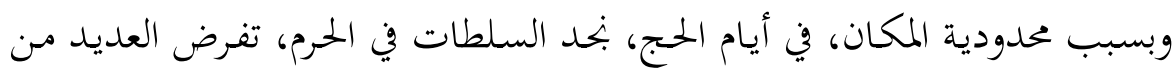

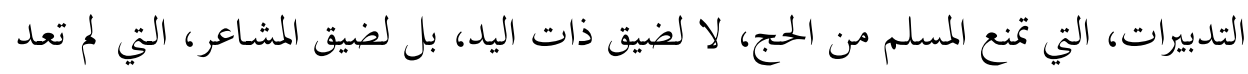

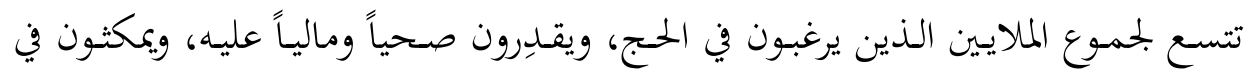
مكة المكرمة ما يقارب الأسبوع.

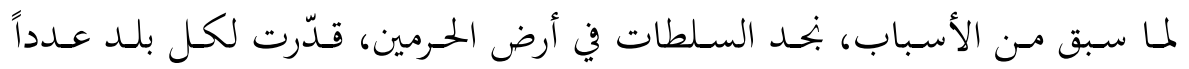

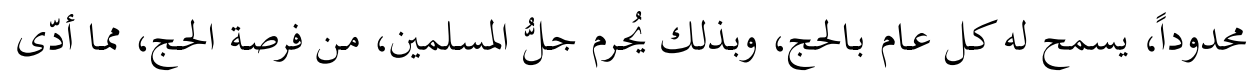

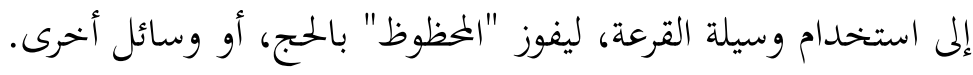

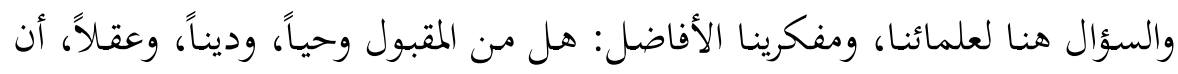
يفرض الله سبحانه فريضة لا يمكن القيام بها؟!

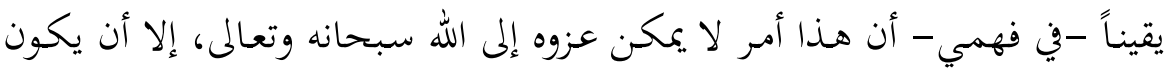

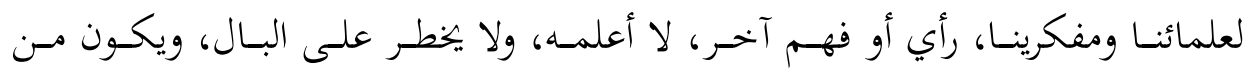

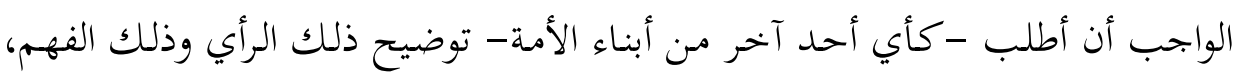

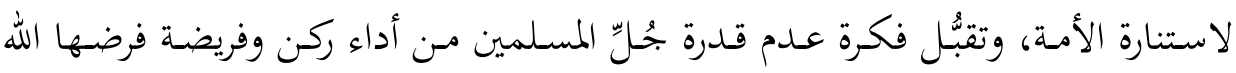
على كل مسلم. 


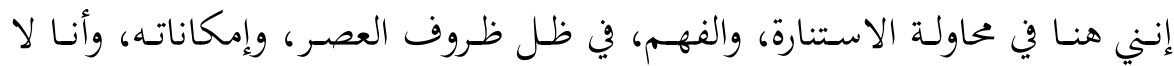

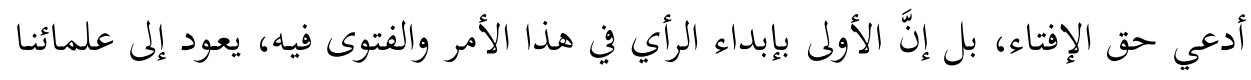

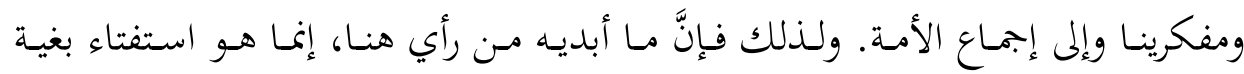

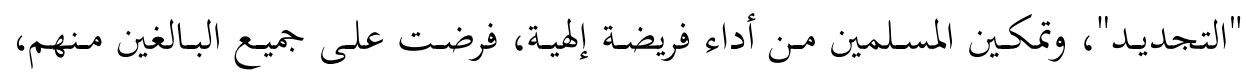

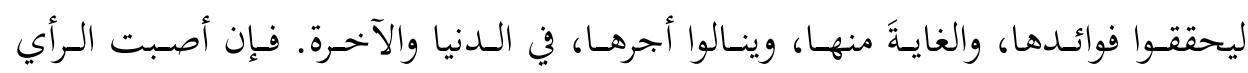

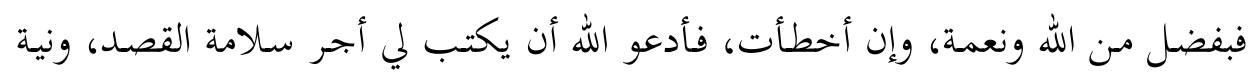

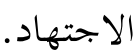

وهكـذا فإن الذذي أراه على أسـاس مـن نصوص الوحي القرآنية أن "الـدين" هـو

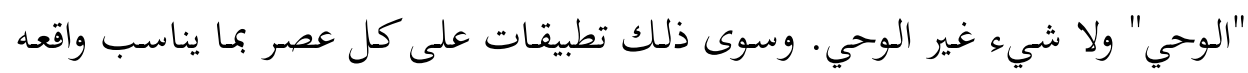
ويستفاد من التطبيقات حكمَتَها.

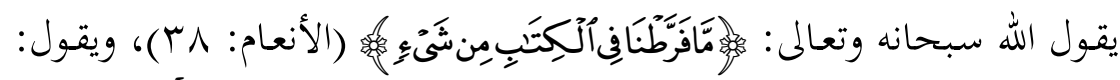

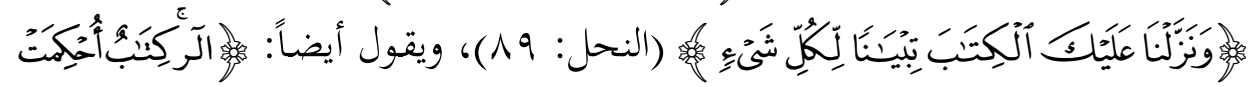

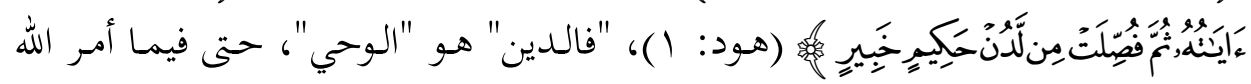

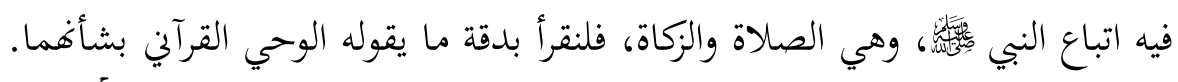

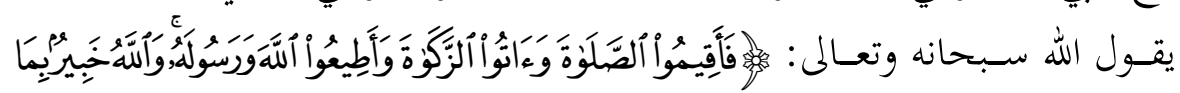

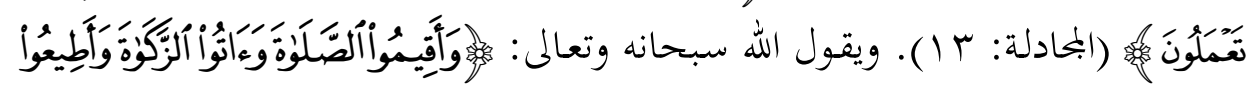

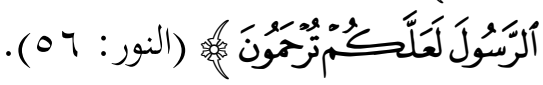

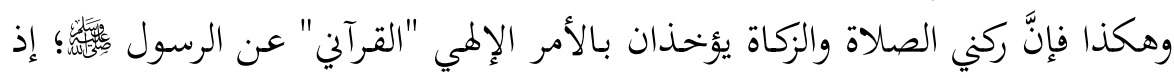

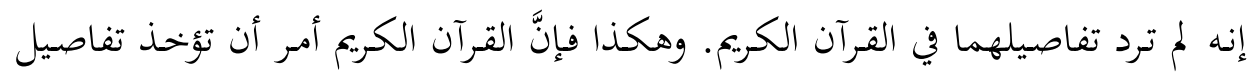

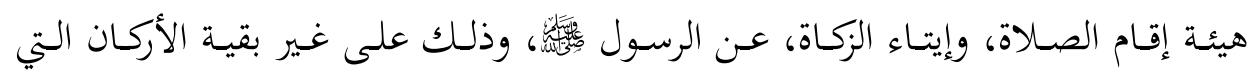

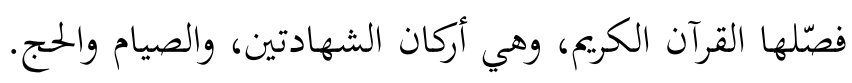

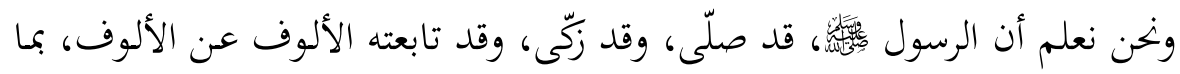

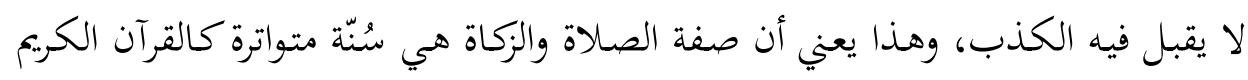

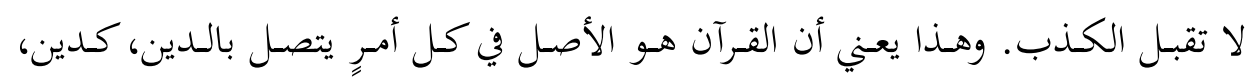

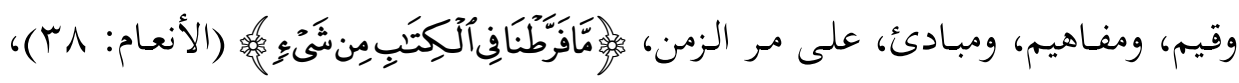




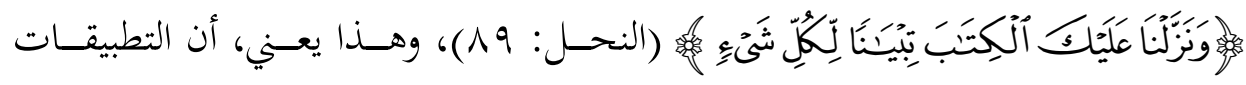

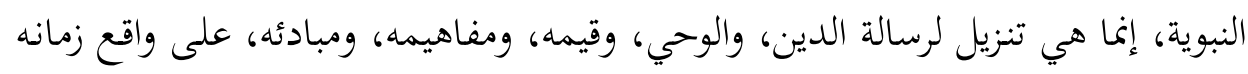

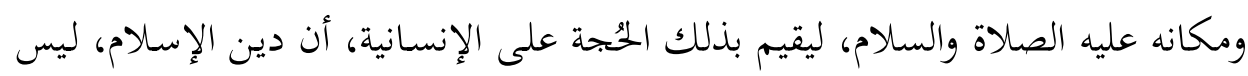

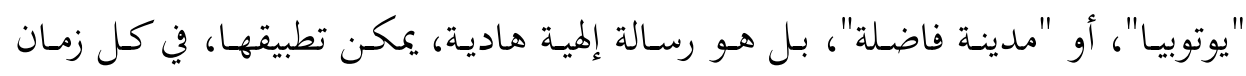

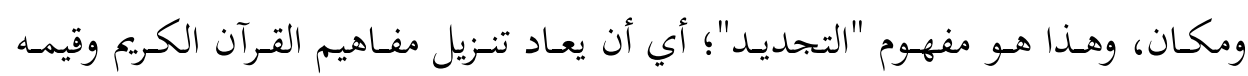

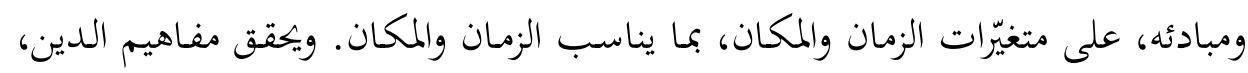

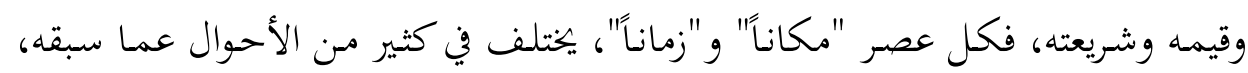
وما يأتي بعده.

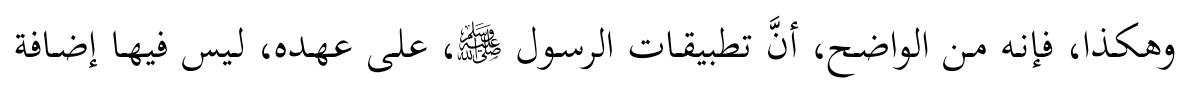

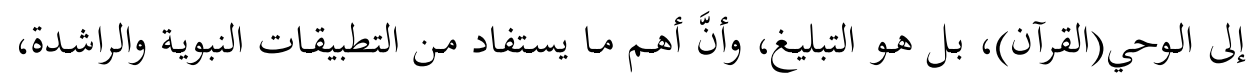

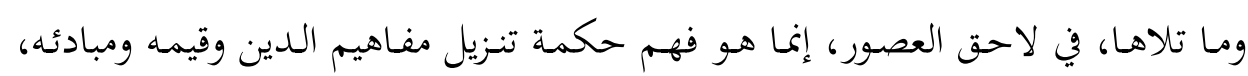

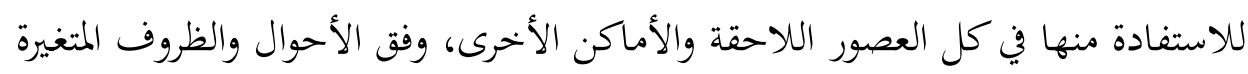
والمتجددة للزمان والمكان. - مان.

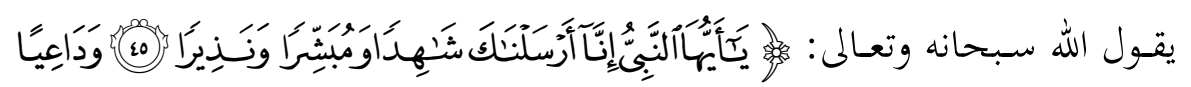

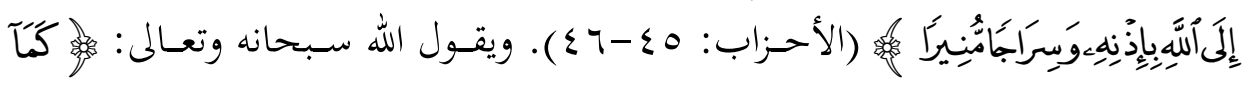

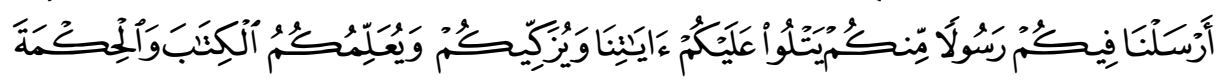

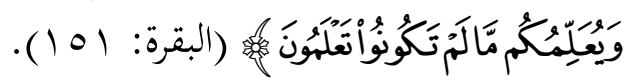

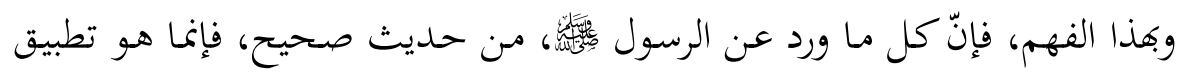

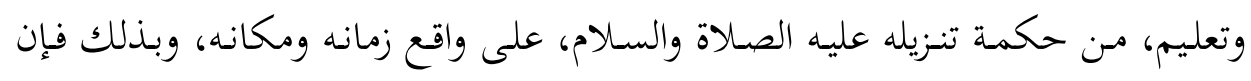

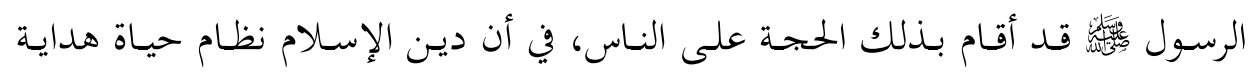

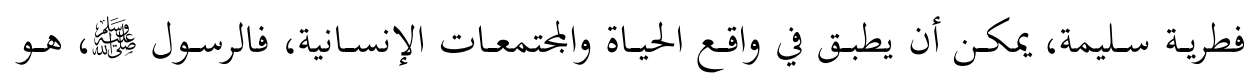

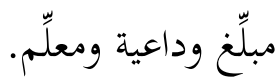

وهكذا؛ فإن صحَّتْْ هذه الفرضيات، بناءً على ما سبق، فالسؤال: ألا يرى علماؤنا

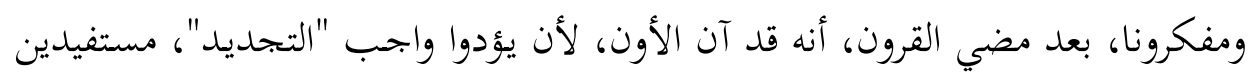

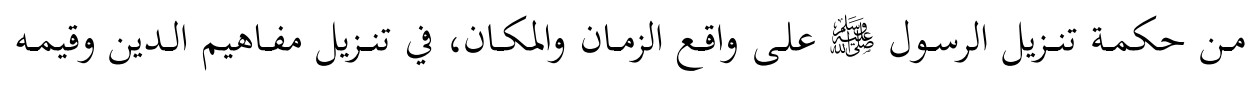


ومبادئه على عالمنا المعاصر، وما طرأ على الإنسانية من تغيرات عظمى، على حاجاته،

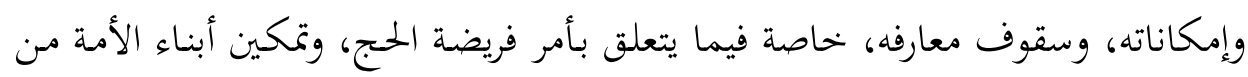
أدائها؟!

\section{ثالثاً: المرجعية القرآنية في فريضة الحج في هذا العصر}

كل ما سبق -في رأيي - يوجب علينا أن نعود إلى القرآن الكريم، لإعادة النظر في أمر أداء فريضة الحج، من منطلق القرآن الكريم، لا منطلق التطبيقات الحرفية لزمان العهد

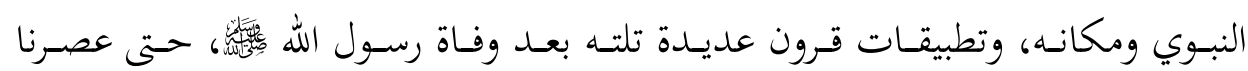
الحاضر.

لقد كان سكان الأرض، كما ذكرنا قبل هذا العصر يعدون بالملايين، وعدد الحجيج بالألوف، وبذلك فإنه لا بحال للمقارنة، بماكان عليه الحال، على ما سبق من العصور وما هو عليه حال اليوم، حيث كان للحج مشقة عظيمة، يقطع الحاج فيها الشهور بل السنين، مشياً على الأقدام، وركوباً على الرواحل ليبلغ البيت الحرام في مكة المكرمة.

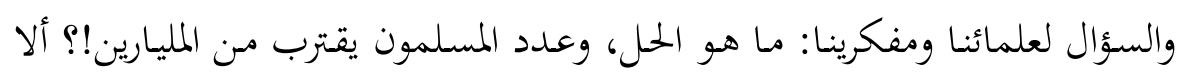

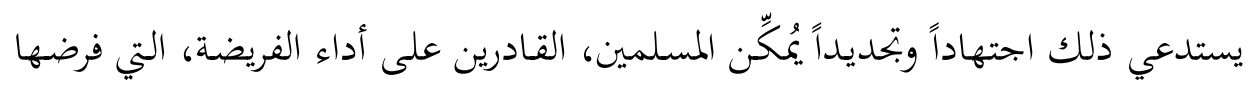

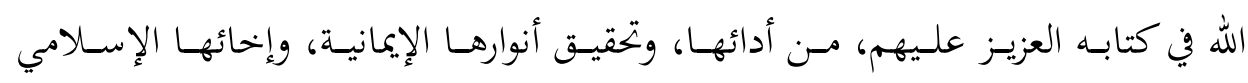

$$
\text { الإنساني، في قلب كل مسلم؟! }
$$

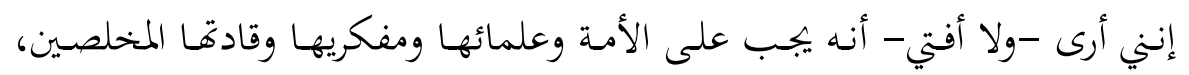
الرجوع إلى القرآن الكريم بشأن هذه الأزمة، ولا بد أننا سنجد أن نصوص القيى الترآن آن الكريم

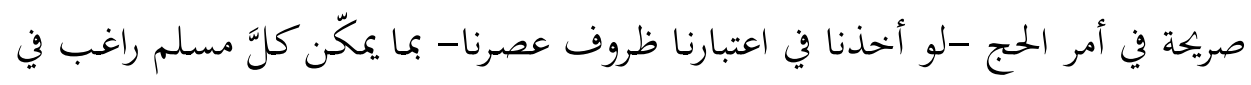
الحج مهما بلغ عدد الحجيتج. إنّه مما يسهـم في عون أكبر عدد مـن المسلمين مـن أداء فريضـة الحهج -إلى أن تُحل

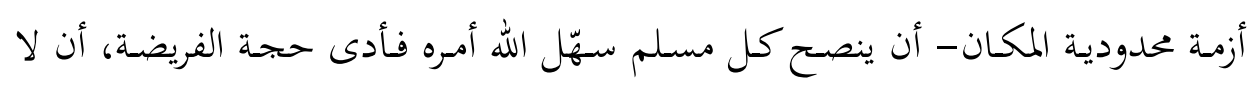

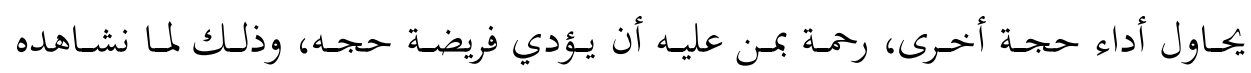




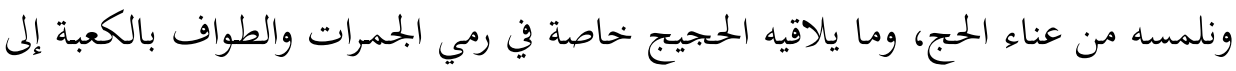

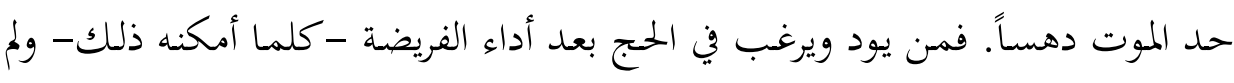

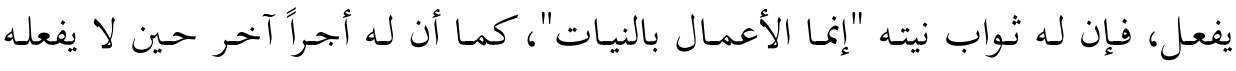

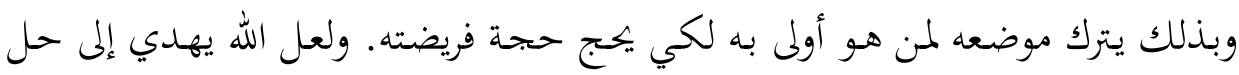

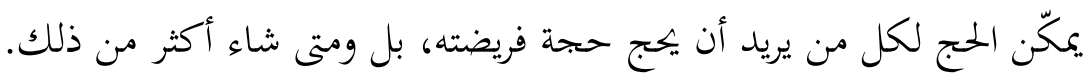

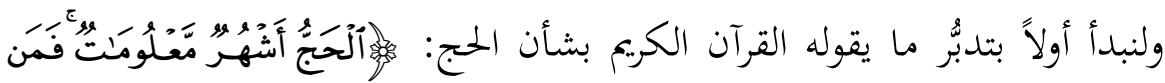

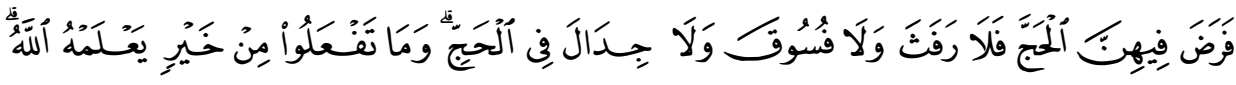

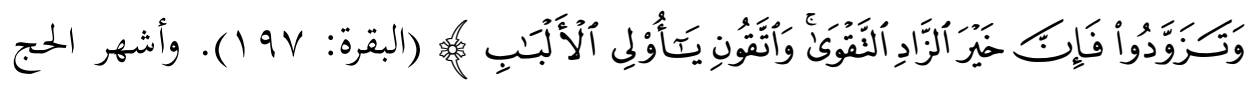

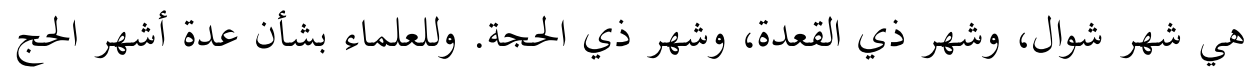

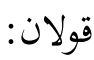

القول الأول: إنَّ أشهر الحجبّ شهران وعشرة أيام وهي: شوال وذو القعدة وعشرٌ من

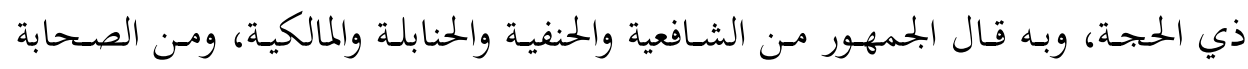

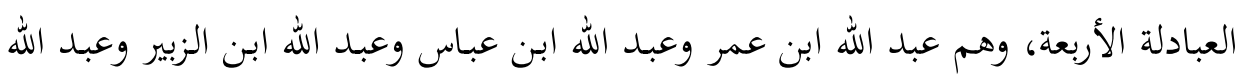

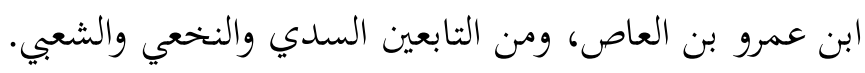

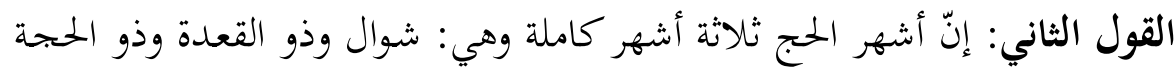

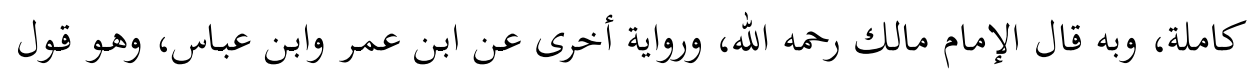

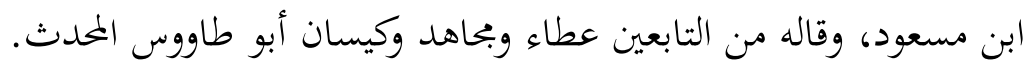

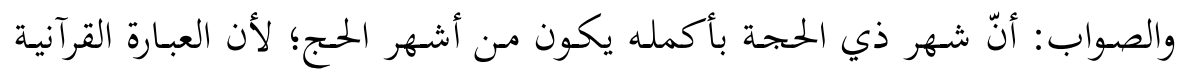

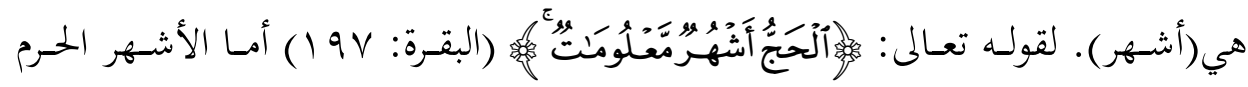

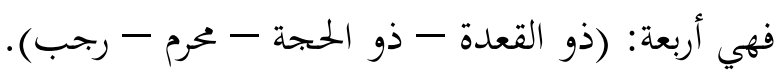

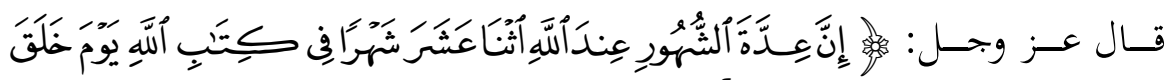

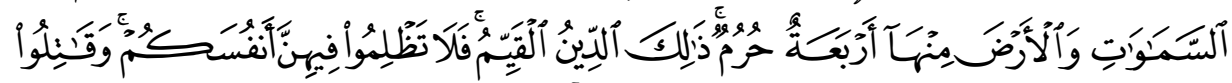

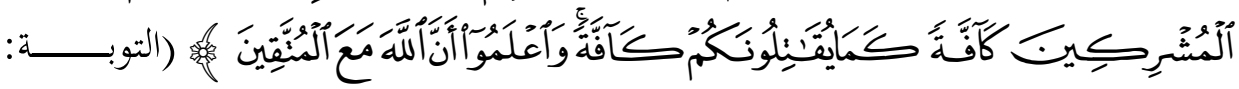
צץ). وروى البخاري في صحيحه عن النبي 


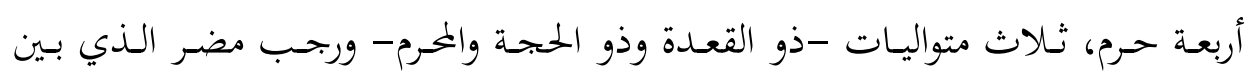

$$
\text { جمادى وشعبان. }
$$

وفي شهر رجب يبدأ الحجيج بالتوجه إلى البيت الحرام، وفي شهر المحرم يعود الحجيج

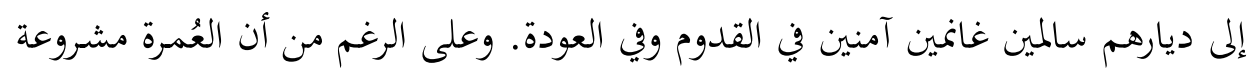

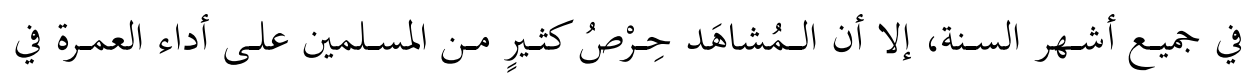

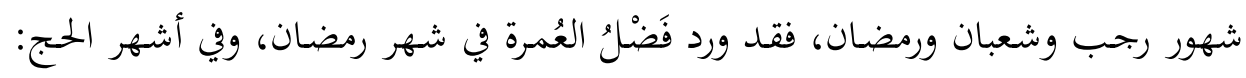

$$
\text { شوال وذي القعدة وذي الحجة وفي شهر رجب. }
$$

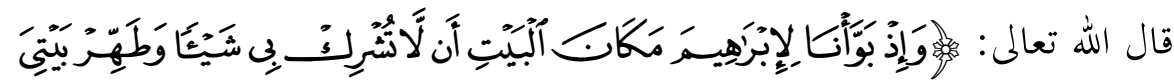

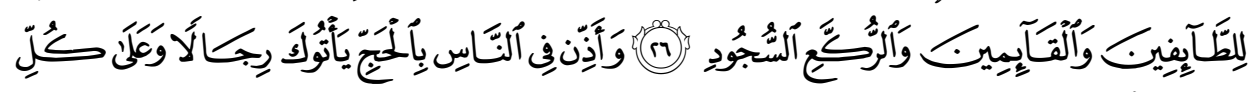

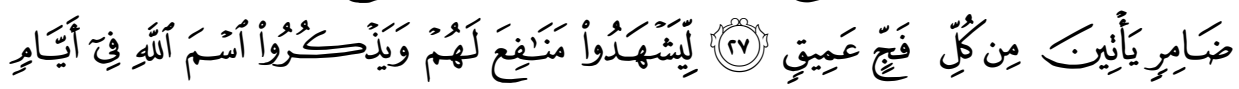

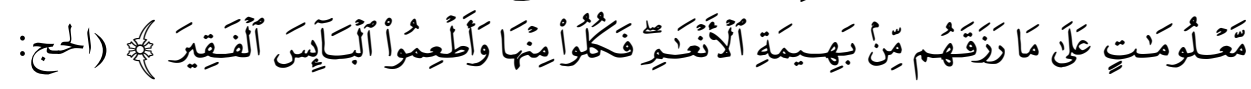
. (YN-YT

وإذا اتضَّح في الذهن كل ما سبق، من اعتبارات وإشكالات، فهل الأولى أن نأخدذ

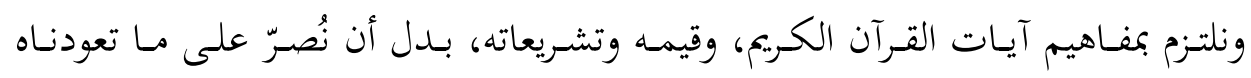

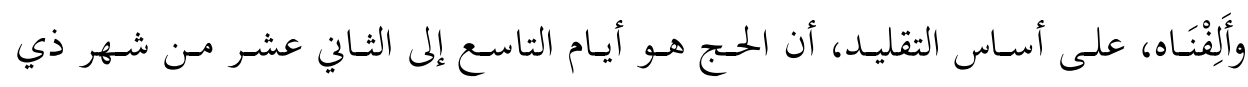

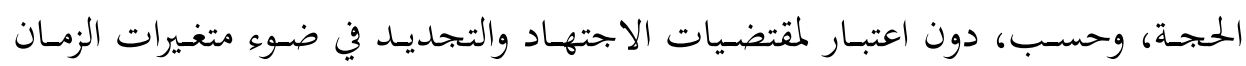

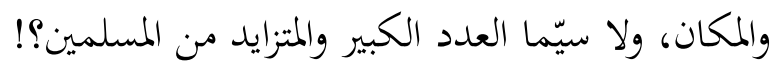

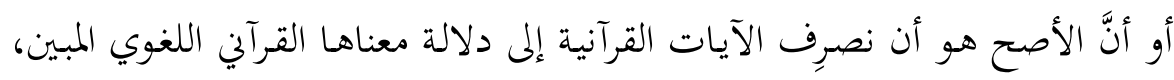

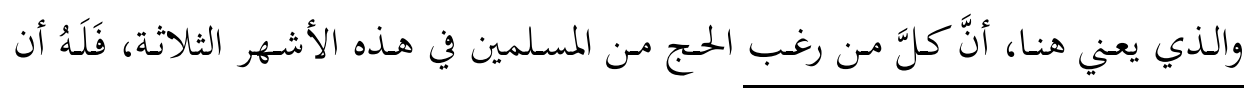

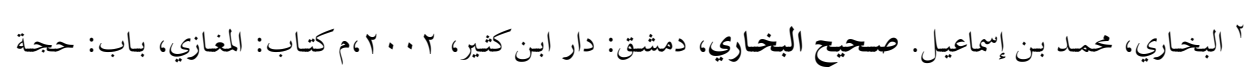

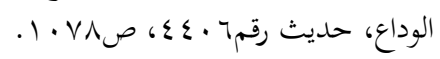

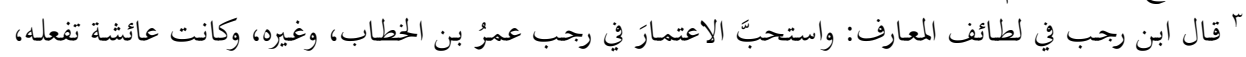

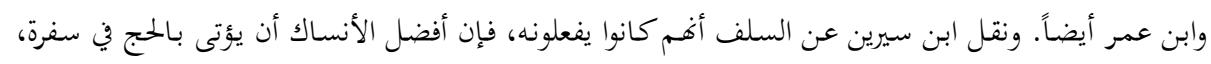

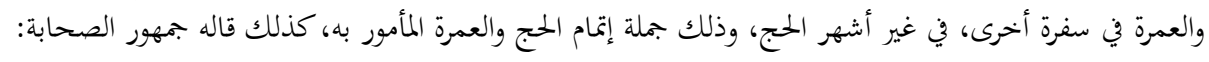

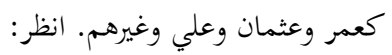
- ابن رجب الحنبلي، الحافظ أبو الفرج عبد الرمن بن أمدمد. لطائف المعارف فيما لمواسم العام من الوظائف،

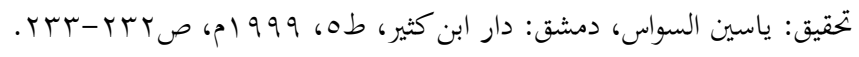




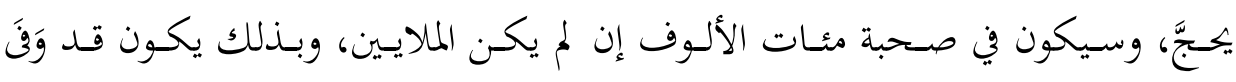

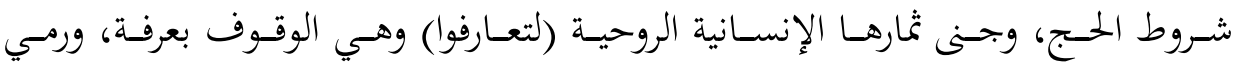

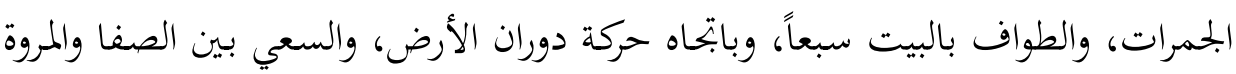
سبعاً، والحلق أو التقصير. ولطواف باليت.

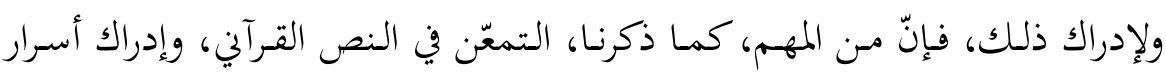

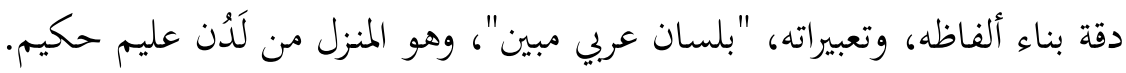

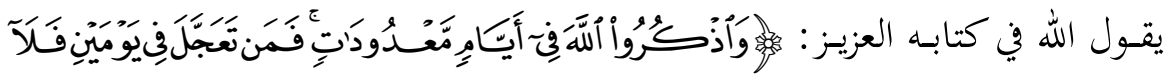

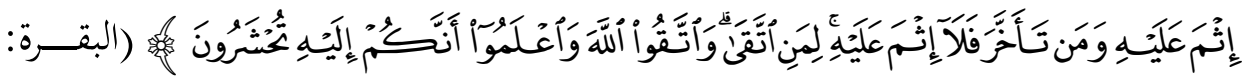
$\cdot(r \cdot r$

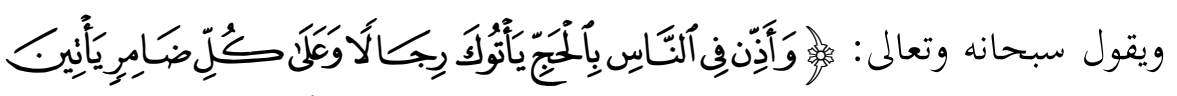

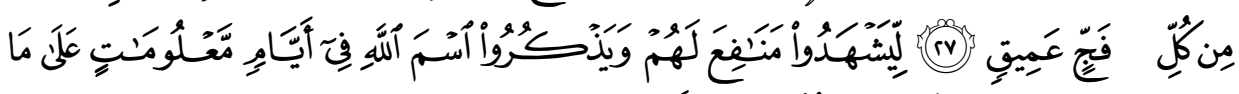

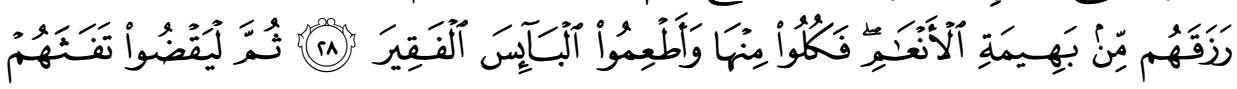

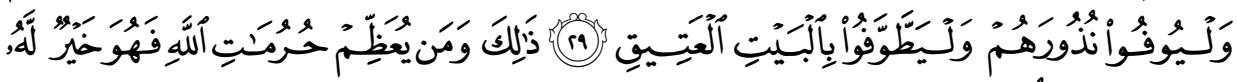

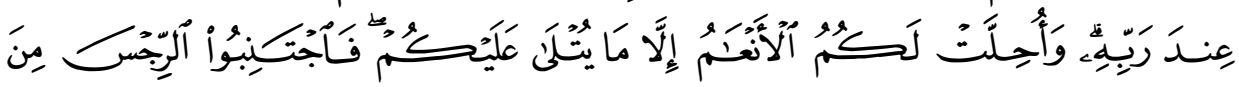

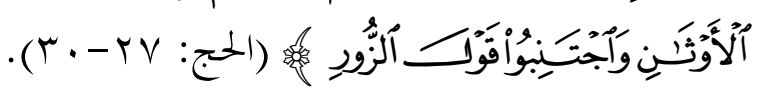

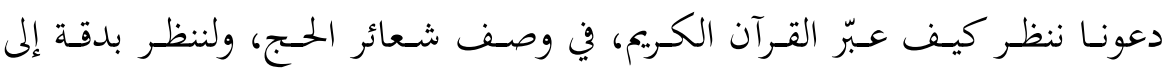

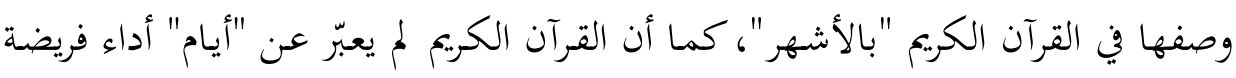

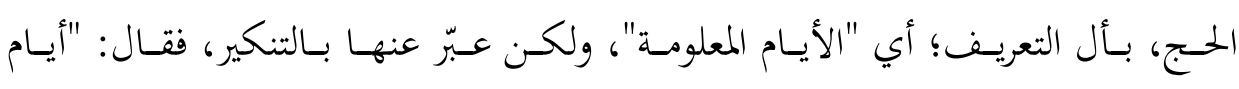

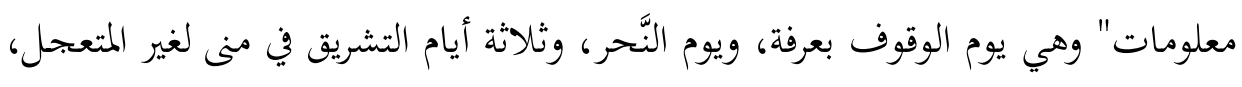

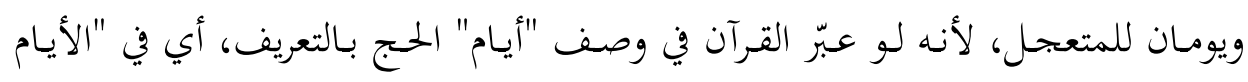

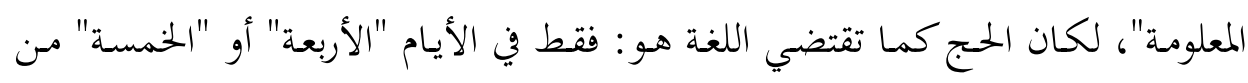

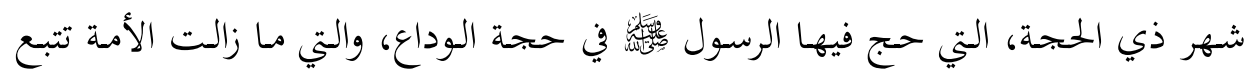
سنته عليه الصلاة والسلام.

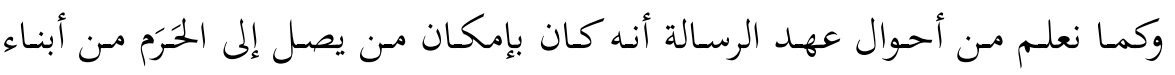

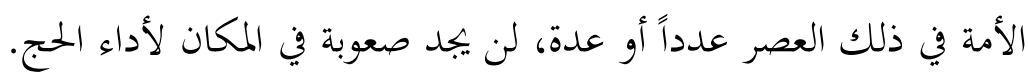




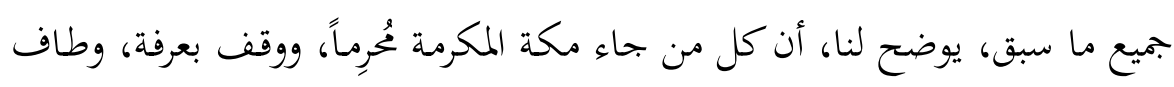

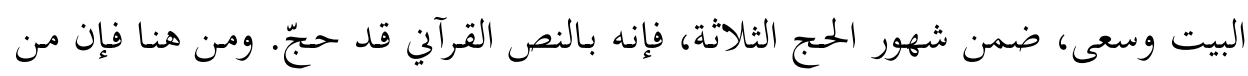

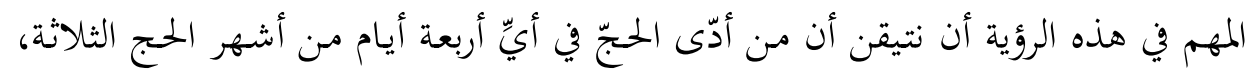

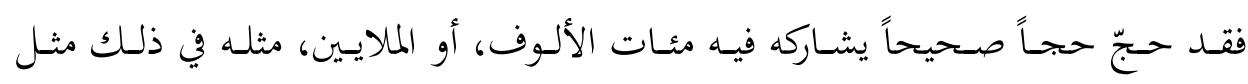

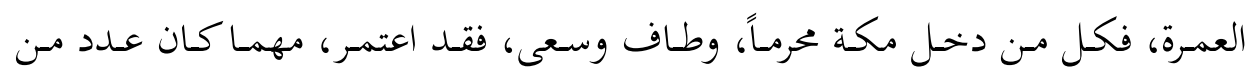

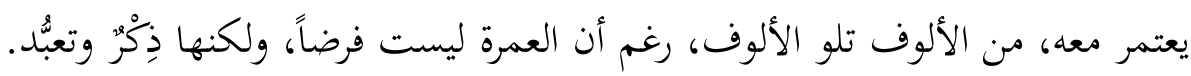

\section{رابعاً: عيد الأضحى ويوم النحر}

وهناك أمر آخر، جاء فيه التعريف دقيقاً، وهو أن أول يوم، بعد يوم الوقوف بعرفة

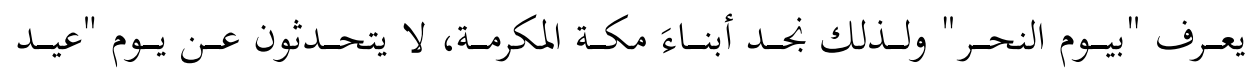

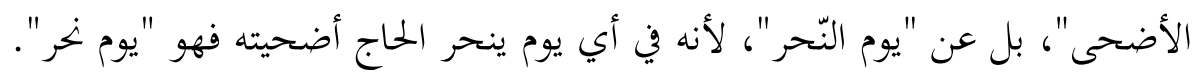

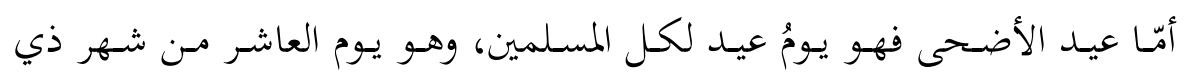

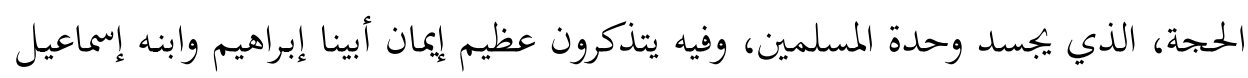

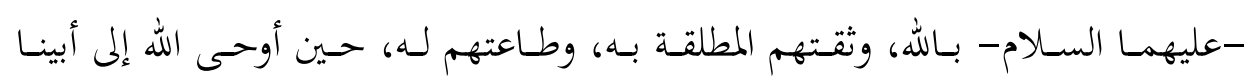

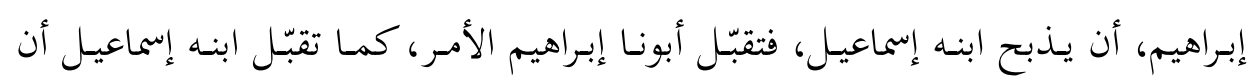

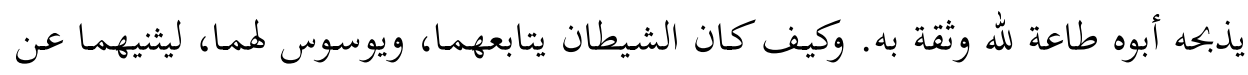

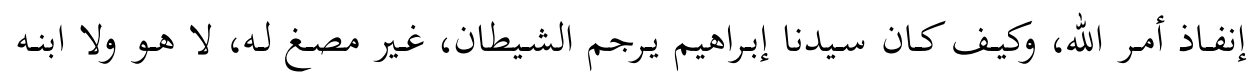

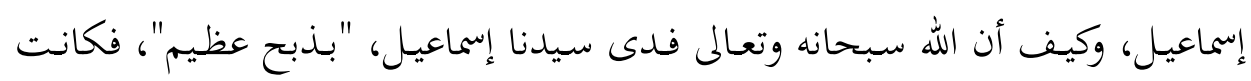

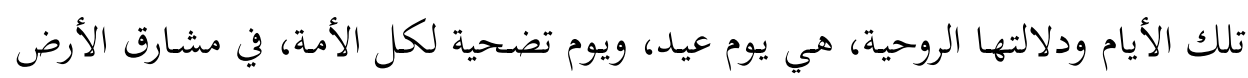

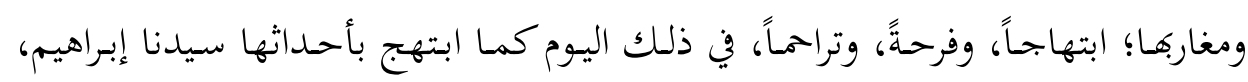

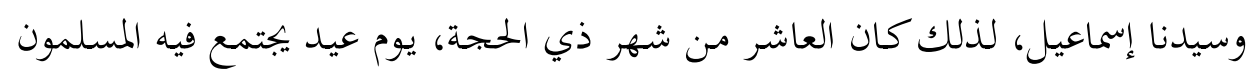

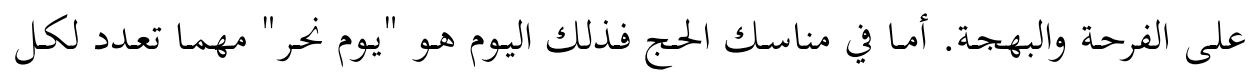
من حج إلى عرفة في أشهر الحج الثلاثة.

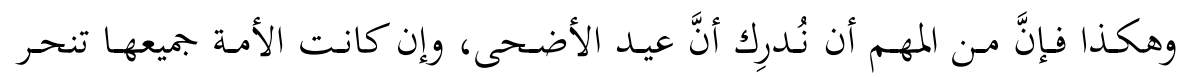

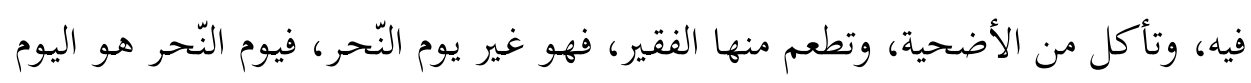




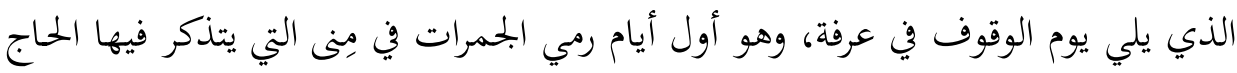

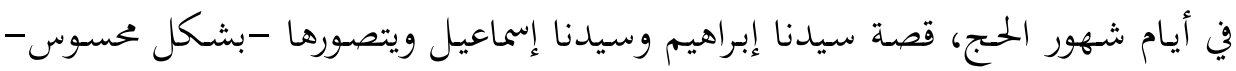

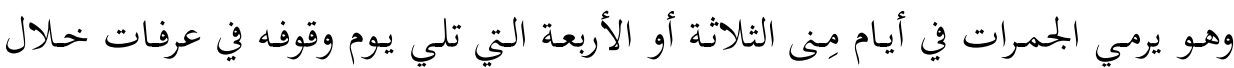
أيام شهور الحج الثلاثة. وهكذا فإن "يوم النّحر" يحمل دلالته مهما تعدد من يقومون به خلال أداء شعائر الحج في شهور الحج الثلاثة مهما كان عدد الحجيج.

\section{خامساً: رزق مكة وخدمة الحجيج بين الأمس واليوم}

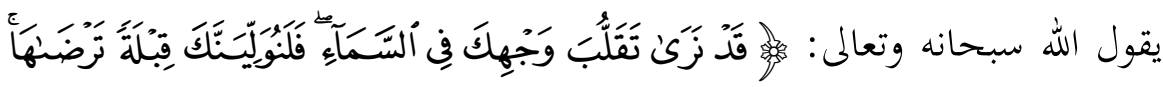

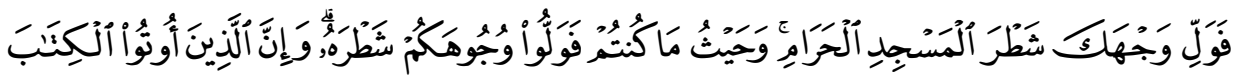

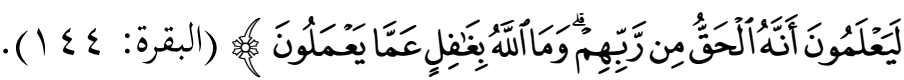

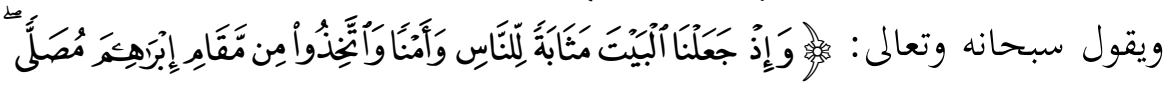

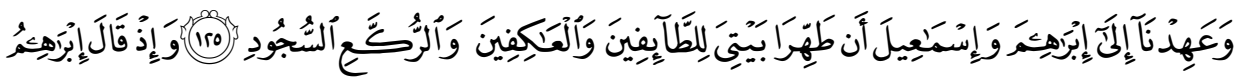

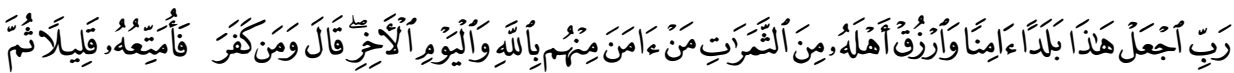

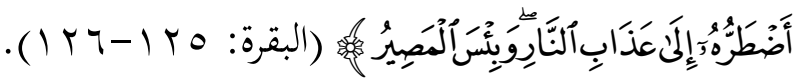

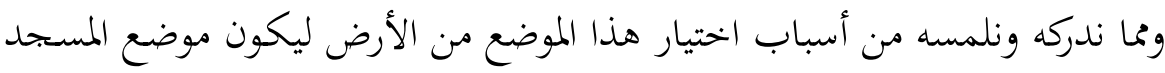

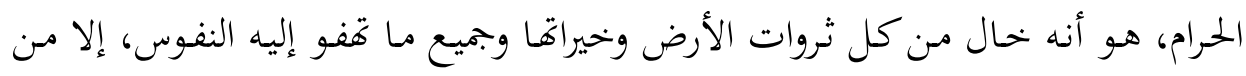

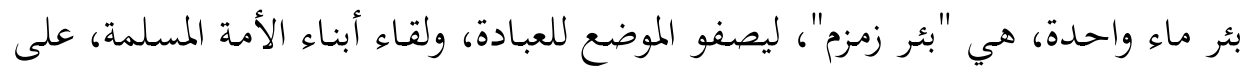

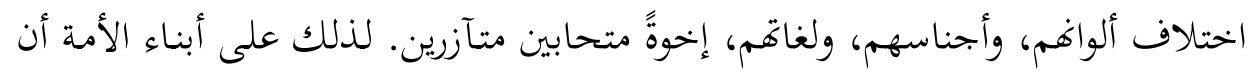

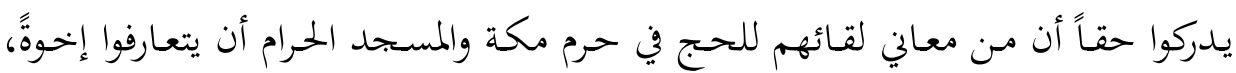
وينبذوا جميع ألوان الكبر والعنصريات.

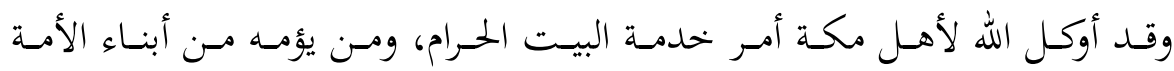

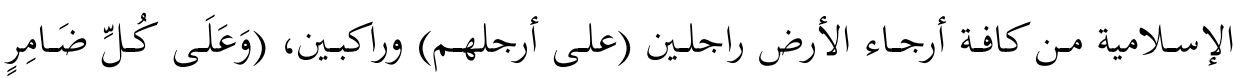

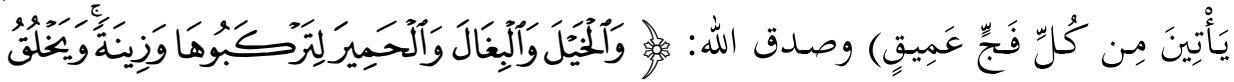




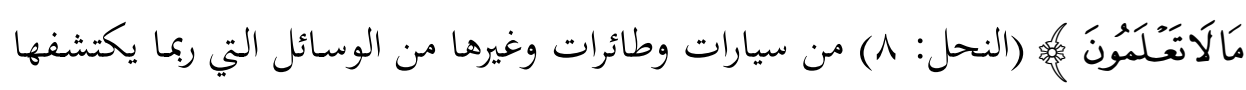
الإنسان ولا نعلمها الآن.

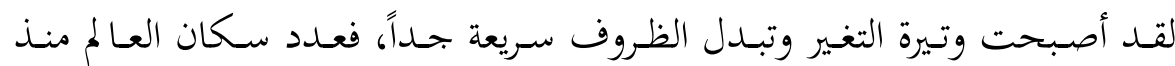

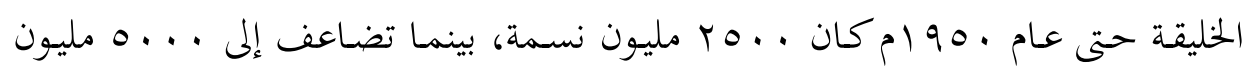

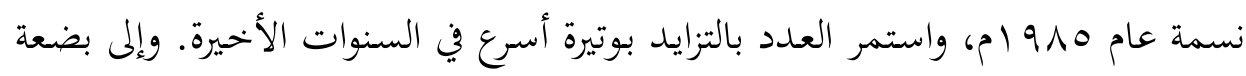

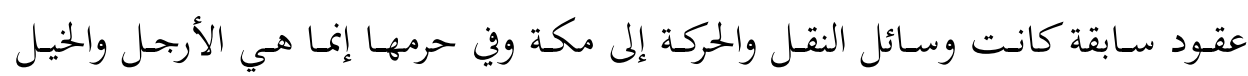

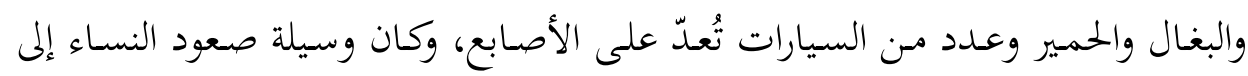

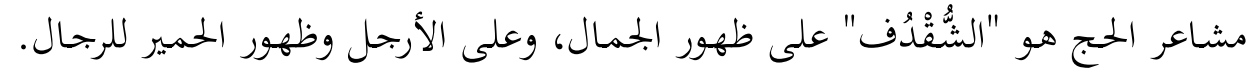

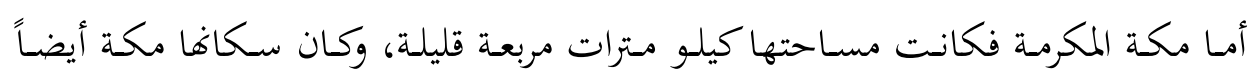

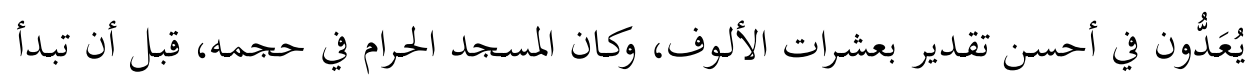
التوسعات يسع سكان مكة وضيوفها من الحجيج دون ضيق أو أو عناء.

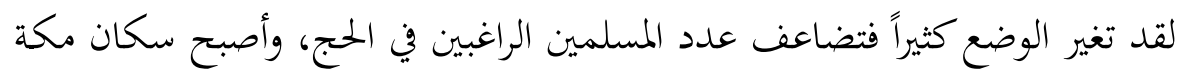

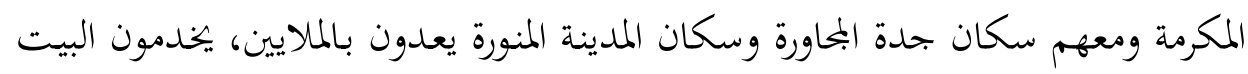

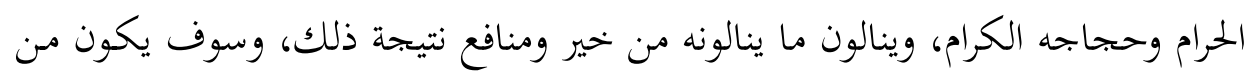

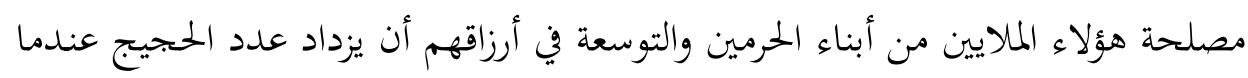

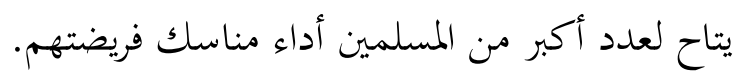

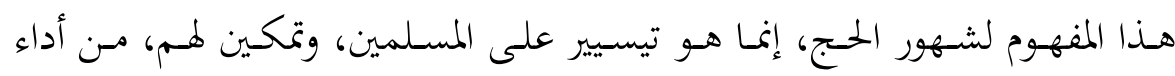

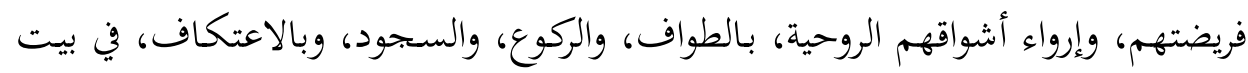

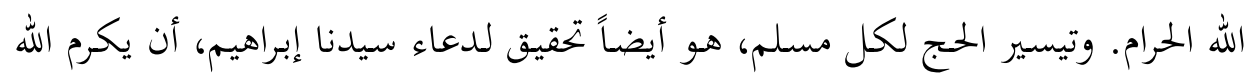

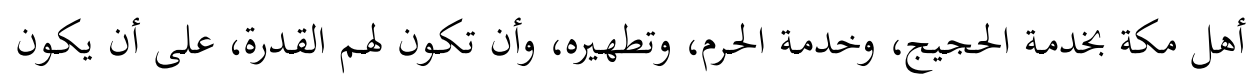

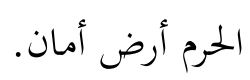

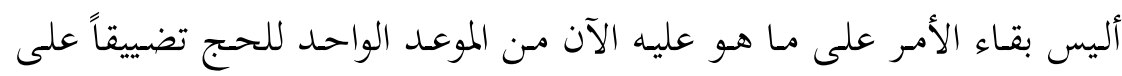

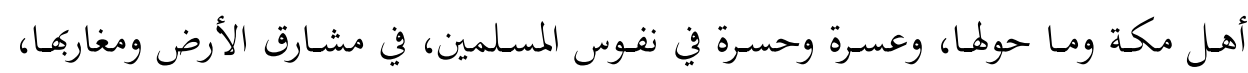
حين يمنعون من الحج، ولقاء عرفات، والطواف بالبيت، والصلاة والاعتكاف في في المستحد 


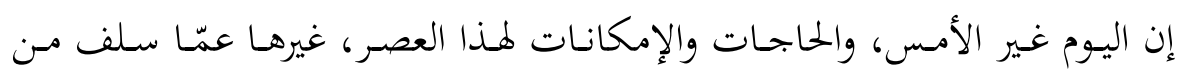

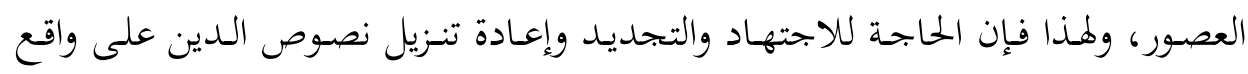

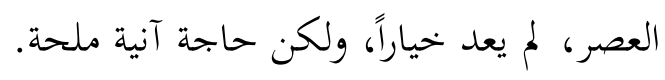

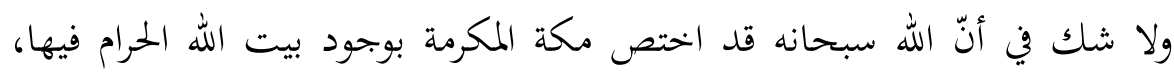

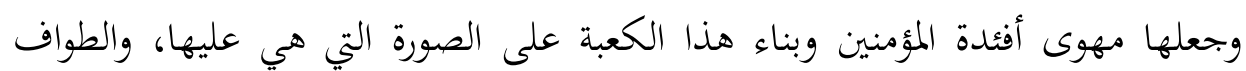

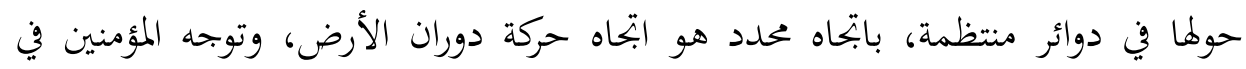

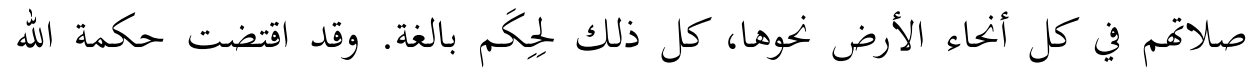

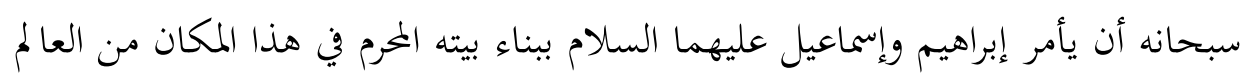

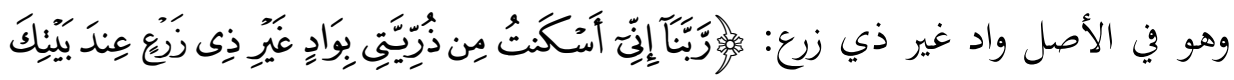

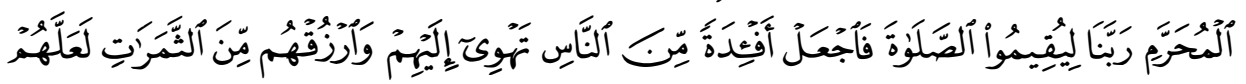

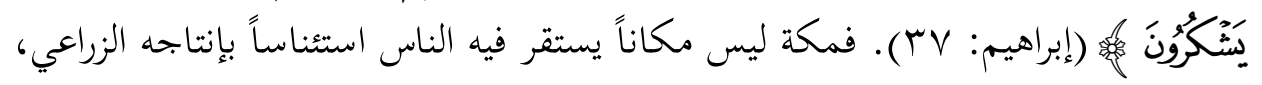

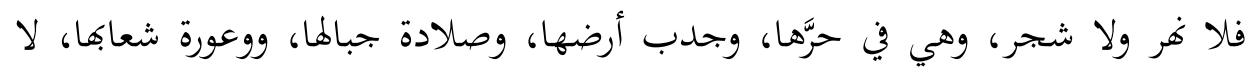

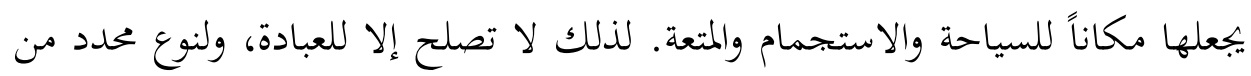
العبادة على وجه الخصوص وهو عبادة الحج.

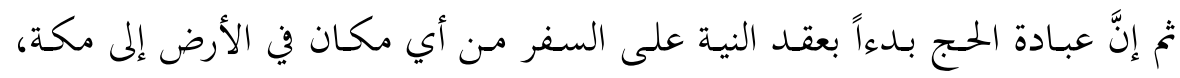

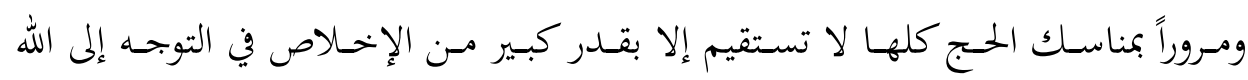

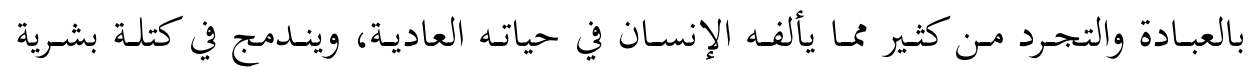

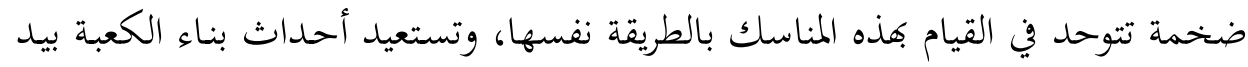

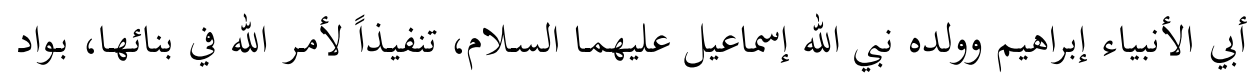

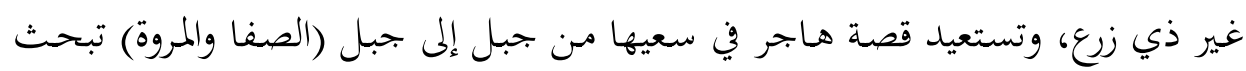

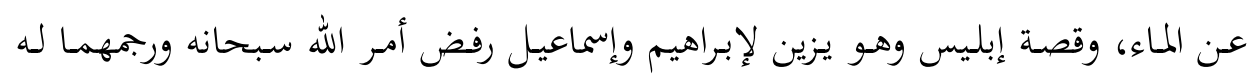

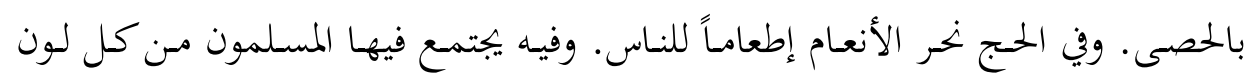

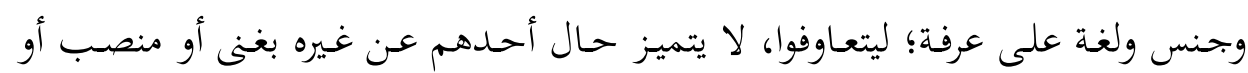

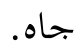
لذلك لا معنى أي يأتي الزائر لمكة لغير هذه العبادة الفريدة. 
الخلاصة:

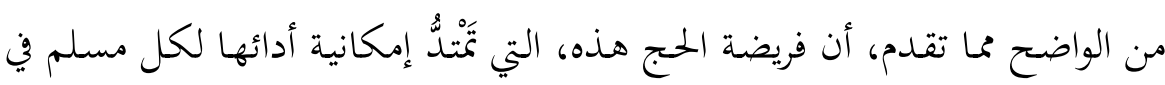
شهور الحج الثلاثة، وفقاً للمنطوق القرآين، في اجتهاد يستجيب ويتوافق مع حال هـا

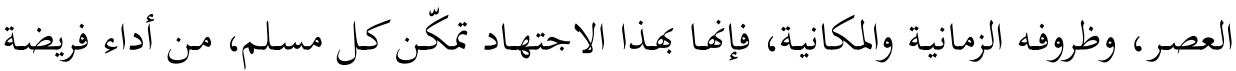

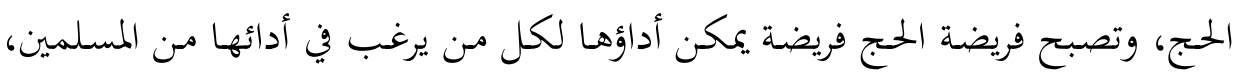

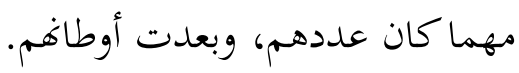

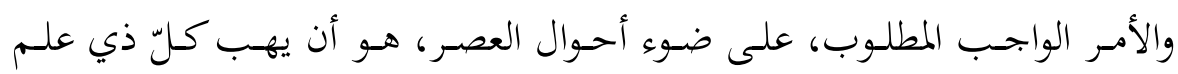
وفضل، ليمعن النظر والفكر والتدبر بكل الجحدية، ويستدعي جميع جوانب الأزمة الراهنة

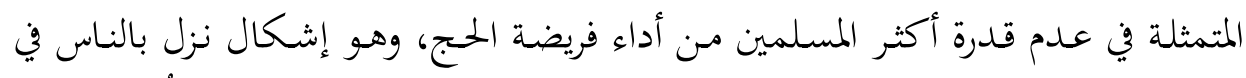

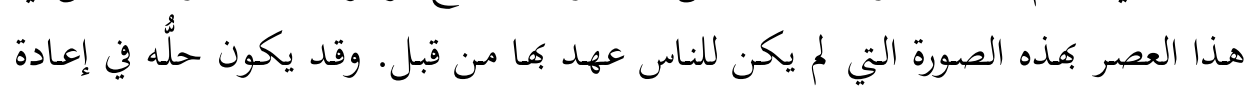

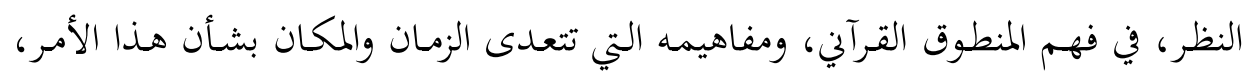

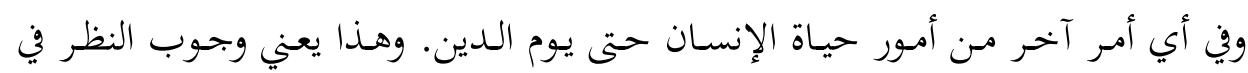

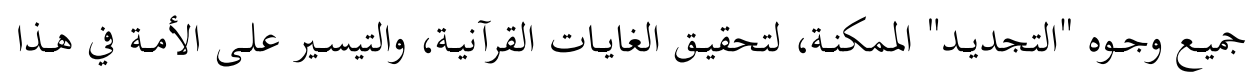
العصر، وفيما سيأتي من عصور.

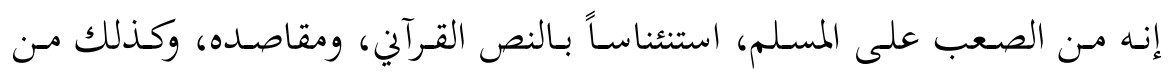

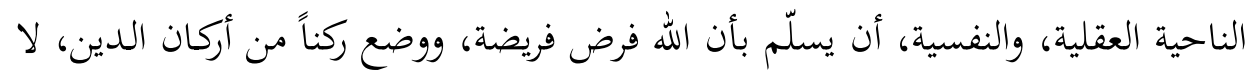
يمكن أداؤه، وذلك بسبب الاستمرار على أحوال العصور السالفة، التي كانت تقصر أداء فريضة الحج كل عام على أربعة أيام فقط هي أيام (التاسع والعاشر والحادي عشر والثناني

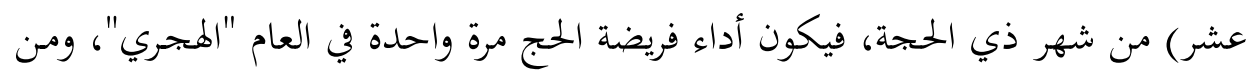

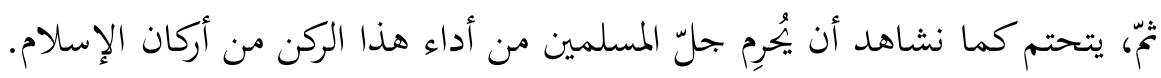

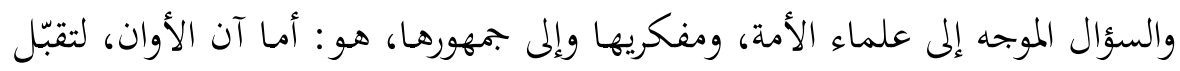

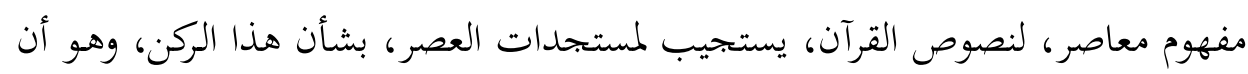

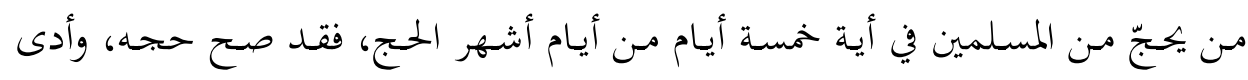
فريضته وحقق الغايات الروحية والحياتية من حجه؟! 


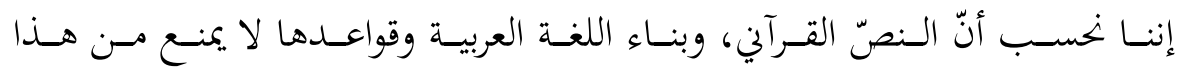

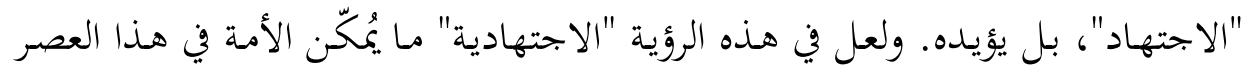

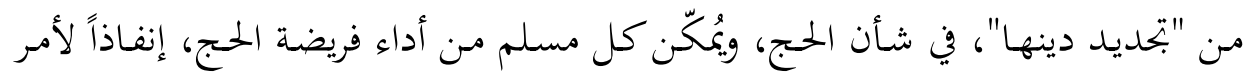

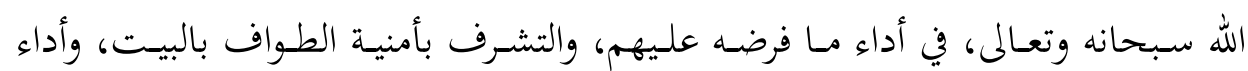

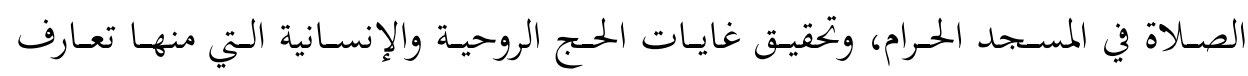

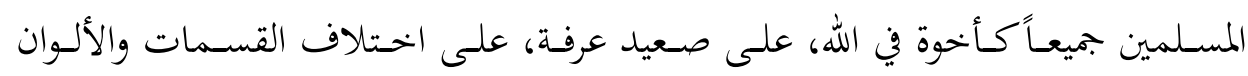

$$
\text { واللغات والأوطان. }
$$

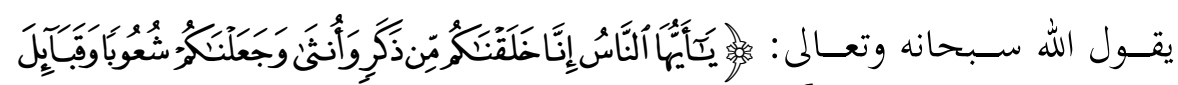

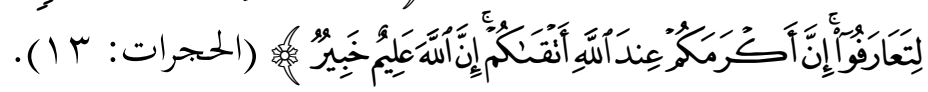

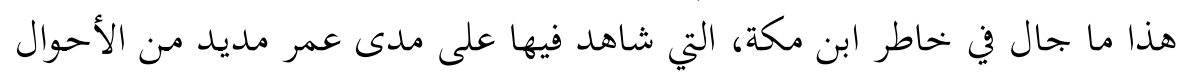

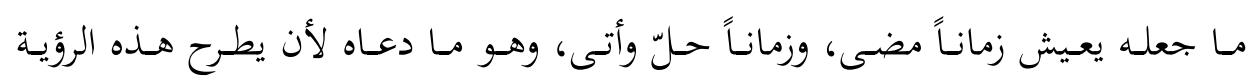

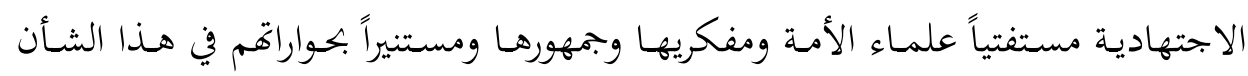
العظيم، الذي يهم الأمة في كل مكان.

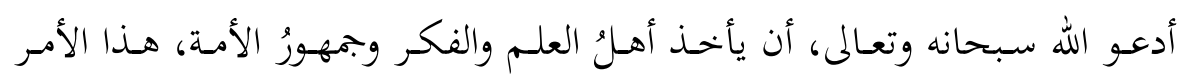

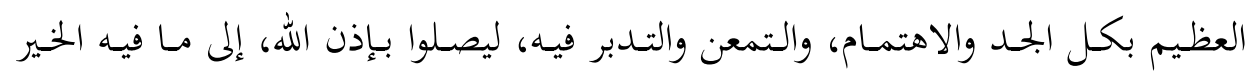
والصواب. فلا بتحتمع أمة الإسلام على ضلالة. والله سبحانه هو الهادي إلى سواء السبيل. 